\title{
Energy Efficiency and Firm Growth
}

\author{
Bongseok Choi ${ }^{*}$, Wooyoung Park ${ }^{* *}$, Bok-Keun Yu ${ }^{* * *}$
}

The views expressed herein are those of the author and do not necessarily reflect the official views of the Bank of Korea or Korea Energy Economics Institute. When reporting or citing this paper, the author's name should always be stated explicitly.

* Research Fellow, Korea Energy Economics Institute, Phone: +82-52-714-2150; Email: bchoi4@keei.re.kr

** Associate Research Fellow, Korea Energy Economics Institute, Phone: +82-52-714-2221;

Email: parkw@keei.re.kr

*** Head, Advanced Economics Team, Research Department, The Bank of Korea, Phone: +82-2-759-5284;

Email: bokyu@bok.or.kr

We are grateful to Won Gyu Choi, Jin-Su Park, Seryoung Park, Sunyoung Jung and participants in the seminar at the Bank of Korea whose useful comments have significantly improved this paper. All the remaining errors are our own. This joint paper was drafted while Dr. Bok-Keun Yu was working at the BOK Economic Research Institute. 


\section{Contents}

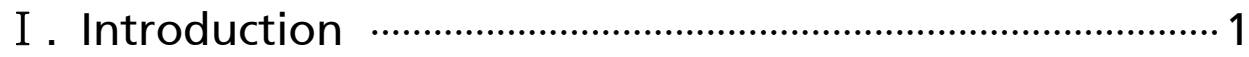

II. Measurement and Comparison of Energy Efficiency $\cdots .3$

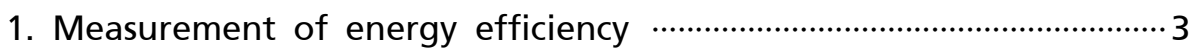

2. Comparison of energy efficiency by country and industry ………...5

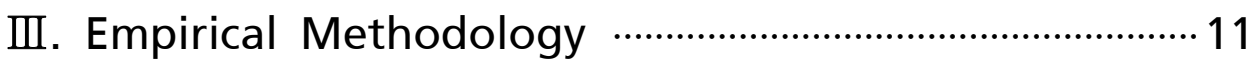

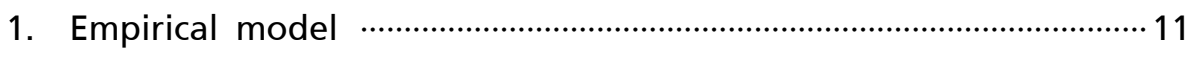

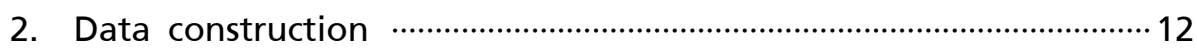

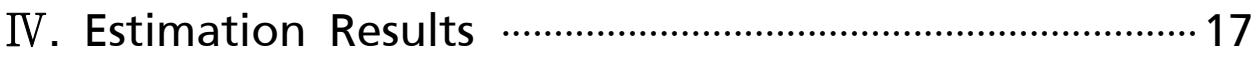

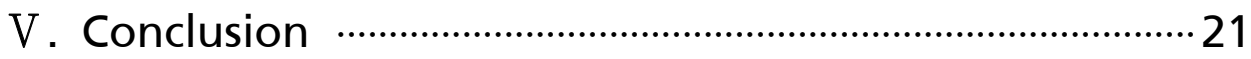

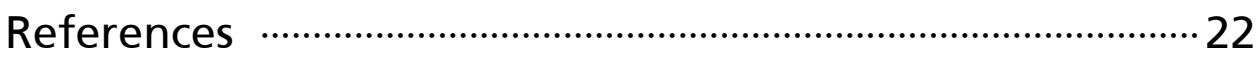




\section{Energy Efficiency and Firm Growth}

Using micro-level data, we attempt to identify the causal relationship between energy efficiency and firm growth in 6 countries (France, Germany, Japan, Korea, the U.K., and the U.S.) and 22 manufacturing industries during the period of 1990-2005. We run a panel regression of firm growth in a country- and industry-specific relative energy efficiency (REE) to the corresponding industrial sector in the benchmark country (the U.S.) in addition to the traditional energy efficiency measure (EE) using simply the inverse of energy intensity, after controlling several firm, industry, and country variables.

We find that REE and EE might have a somewhat different impact on firm growth in terms of profits, although improvements in both REE and EE have a positive effect on the growth rate of sales and capital accumulation. This result indicates that REE as well as EE need to be considered when analyzing the linkages running between energy efficiency and firm growth. Compared to the six country case, we find that the efficient use of energy inputs in Korea has made a smaller contribution to firm growth.

Keywords: Energy efficiency, Energy intensity, Economic growth, Firm growth

JEL classification: D24, O13, Q43 


\section{I . Introduction}

The patterns of energy uses vary with the phases of economic development. Several authors have argued that the energy intensity of an economy resembles an inverted U-shape across increasing levels of per capita income, where energy intensity is defined as the quantity of energy consumed per unit of economic output (Medlock and Soligo, 2001). This aspect could be mainly due to changes in the composition of GDP by industry as well as variation of energy efficiency itself within each industry in the course of economic development. Specifically, industrialization at an early stage resulted in large increases in industrial energy use. Then, as economies move into the post-industrial phase of economic development, the service sector grows faster than the manufacturing sector, and energy demand grows at a slower rate for given increases in GDP. On the other hand, more energy-efficient capital is deployed as technology advances; the energy requirements for a given level of output decline, allowing economic activities to expand without much increase in energy demand. For example, the trend in energy intensity for the U.S. from 1920 to 2005 was downward, which indicates lower energy consumption unit of per capita income.

Improving energy efficiency has been one of the top priorities for economic growth at the post-industrial phase of economic development, where energy efficiency is the reciprocal of energy intensity. In particular, it has received growing attention as a key component of sustainable development. For both academia and policy makers, energy efficiency has been considered one of the most important factors in tackling potential environmental risks by reducing $\mathrm{CO}_{2}$ emissions as well as in strengthening industrial competitiveness and energy security.

This paper basically investigates the causal relationship between energy efficiency and economic growth. There have been a host of theoretical and empirical studies regarding the links between the two. By and large, energy

efficiency has changed over time and across countries (Ang and Zhang, 2000; Roca and Alcántara, 2001; Duro et al., 2010; Warr and Ayres, 2010; Vogit, Cian, Schymura and Verdolini, 2014). Stern (2011) argues that energy input is also a critical factor in the production process together with capital and labor. In this 
respect, it has been documented that energy efficiency contributed to economic growth through a rise in total factor productivity (Schurr, 1982; Jorgenson, 1986; Inhaber and Saunders, 1994; Murrillo-Zamorano, 2005). However, there are also many papers arguing that improved energy efficiency can lower the cost of producing energy-intensive goods and create more energy demand known as the "rebound effects (Greening et al., 2000; Sorrell, 2009; Azevedo et al., 2012; Borenstein, 2013).”

Duro et al. (2010) argue that the disparities between countries in the energy efficiency levels are mainly related to differences in sectoral structure as well as the degree of energy efficiency itself. This implies that a sectoral approach may be needed in this area. This approach has gathered fresh dynamism with the construction of a new database, the EU KLEMS (Mulder and Groot, 2012). In the above-mentioned literature, much attention has been paid to comparing the main forces that account for changes in energy consumption across countries, while the mechanism of the impact of improvements in energy efficiency on firm growth itself, even though important, remains relatively little studied.

This paper attempts to identify the relationship between energy efficiency and firm growth using the firm level data covering 22 manufacturing industries and six countries (France, Germany Japan, Korea, the U.K., and the U.S.) during the period of 1990-2005. Our primary goal is to examine whether or not the improved energy efficiency had a significant effect on firm-level growth in terms of capital accumulation as well as operating profits (EBITDA: earnings before interest, taxes, depreciation and amortization; labeled profits) and sales.

The degree of contribution of energy efficiency improvements to the growth of energy-intensive industries may well be relatively larger than that on the growth of other industries. In order to reduce distortions derived from variations by industry in each country, we use a relative measure of energy efficiency to the benchmark case, what we term as "the relative energy efficiency (REE)." We refer to the energy efficiency of the U.S. as the benchmark case because it can be assumed that the country is on the technological frontier and also has a market-friendly environment in terms of energy use. We run a panel regression of firm growth in terms of profits, sales and capital accumulation between the REE measures in addition to that between the traditional energy efficiency measures (EE), after controlling for several firm, industry, and country variables. 
The rest of this paper is organized as follows. In Section II, we discuss the measurement and comparison of energy efficiency by country and industry. Section III describes the empirical model and data construction used in our research. Section IV documents the estimation results. Finally, we conclude in Section V.

\section{II . Measurement and Comparison of Energy Efficiency}

\section{Measurement of Energy Efficiency}

In most of the literature on energy economics and policy, improvements in energy efficiency are typically measured by the decline in energy intensity. Energy intensity (EI) is a measure of the energy efficiency of an industry or nation's economy.1) It can be calculated as units of energy per unit of the value added by industry or GDP as a whole in a country.

$$
\text { Energy Intensity }(E I)=\frac{\text { units of energy }}{\text { units of the Value Added (or GDP) }}
$$

One of the most important issues in measurement is to distinguish the growth effect of energy efficiency improvements in energy-intensive industries from those in other industries. As energy efficiency improves, more energy dependent industries are relatively more affected by the efficient use of resources than other industries. For example, industries such as machinery and chemicals require a lot of energy input to produce unit output. Firms in those industries can save energy input costs much more by the decline in energy intensity, and spend it on long-term investment.

1) A better understanding of the factors affecting energy use over time, including the role of energy efficiency, requires indicators based on more detailed data than are available in the IEA energy balances. Such more detailed information is currently available, on a comparable basis, for 11 IEA countries for the period 1974 to 2008, and for 16 IEA countries for the period 1990 to 2008. 
Furthermore, a change in energy intensity may not only be caused by improvements in energy efficiency itself, but also by other country-specific factors such as resource abundance and the regulatory environment of energy policy. For instance, a rise in energy intensity may result from market inefficiency simply because price regulation of energy markets distorts the price mechanism and thus substitution between inputs.2) Since various factors which influence energy intensity differ across countries, information might be contaminated. ${ }^{3)}$ Thus, without considering the heterogeneity in energy uses between industries and/or between countries, it would be misleading to use the aggregate energy intensity indicators to assess energy efficiency.

One way to effectively address this issue is to measure a relative distance of energy efficiency from the corresponding industrial sector of the country with technological frontier and market-friendly environments in terms of energy uses, instead of the country's inverse of energy intensity itself.

Accordingly, we create the concept of "the relative energy efficiency (REE)," a ratio of U.S. industry's energy intensity to the country's industry energy intensity as a proxy for true improvements in energy efficiency relative to the benchmark case. The distance from the benchmark case of industry $k$ and country $c$ is defined as:

$$
\text { Relative Energy Efficiency }(R E E)_{k, c}=\frac{\frac{1}{E I_{k, c}}}{\frac{1}{E I_{k, U S}}},
$$

where $E I_{k, c}$ and $E I_{k, U S}$ are industry $k$ 's energy intensity of country $c$ and the U.S., respectively. This captures country c's attempt to raise energy efficiency within industries compared to the benchmark country.

2) Korea experienced a decrease in oil and gas consumption relative to electricity consumption for heating. This partly results from misguided energy pricing policies, making for market failures rather than the improvement of energy efficiency.

3) For example, almost all IEA countries experienced a decrease of total final energy use per unit of GDP. Between 1974 and 2010, overall IEA energy intensity dropped by $42 \%$, from 0.30 to 0.18 TOE (tons of oil equivalent) per US $\$ 1,000$. These decreases noted across countries can be explained on a case-by-case basis, taking account of factors such as changes in economic structure and energy mix or gains in energy efficiency. 
For the U.S., the value of REE is equal to 1. For countries which use energy less intensively than the corresponding level in the U.S., the value of REE is higher than 1 . In contrast, for countries which consume energy more intensively than the corresponding level in the U.S., the value of REE is lower than 1.

We constructed a new measure to be specific to common industry-specific traits for technological reasons, but unrelated to country-levels and hence universal across countries. This idea, which sets the U.S. as the benchmark case, is not new. For example, lots of measures in the finance literature are analogous to ours in attempting to construct an industry-specific natural measure independent of country-level traits: dependence of external finance (Rajan and Zingales, 1998)4), opaqueness (Durnev, Morck and Yeung; 2004), growth opportunity (Fishman and Love, 2004), and share of small firms (Beck et al., 2008). In spite of these differences in fields, it is confirmed that our new measurement index of energy efficiency is supported by the previous literature.

\section{Comparison of Energy Efficiency by Country and Industry}

To understand not only the differences in the level of energy use across countries, but also the dynamic evolution, we consider the trends of various indicators that are capable of elucidating the link between energy use and country-specific factors. Figure 1 displays the country-level average of EE, REE and natural resource rents per capita for France, Germany Japan, Korea, the U.K. and the U.S. Natural resource rents per capita are the total rents of natural resources, divided by population over age 15 . These are equal to the value of capital services flows rendered by the natural resources - oil, natural gas, coal, mineral, and forest. 5)

4) For example, Rajan and Zingales (1998) examine the impact of financial development on growth by investigating whether industries with a greater need for external financing grow faster in financially more developed countries. They consider an industry's natural dependence on external finance by using the corresponding U.S. industrial sector.

5) Natural resource rents are the difference between the value of natural resource production at world prices and the total cost of production. 
Figure 1 shows that EE has risen for Germany and France even though for the U.K. it has remained stable. In contrast, EE for the U.S. has increased rapidly over the 2000s. From a comparative perspective, the productivity slowdown in Europe is all the more disappointing as U.S. productivity growth accelerated from the mid-1990s - when there was a bust of high productivity in industries producing information and communications technology equipment, and a capital-deepening effect from investing in information and communication technology (ICT) assets across the economy. The EE of Korea has declined since the middle of 1990s. As of 2004, the EE of the U.S. shows the highest number among sample countries,

Figure 1: Energy Efficiency and Per Capita Natural Resource Rents by Country
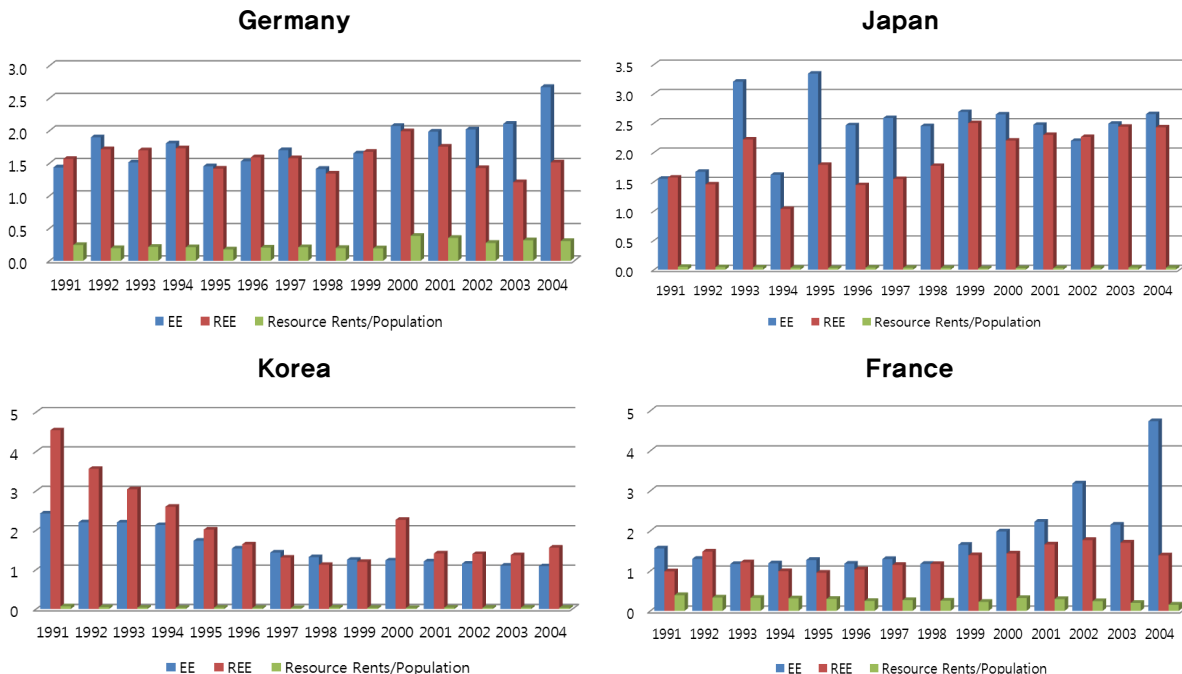

United Kingdom
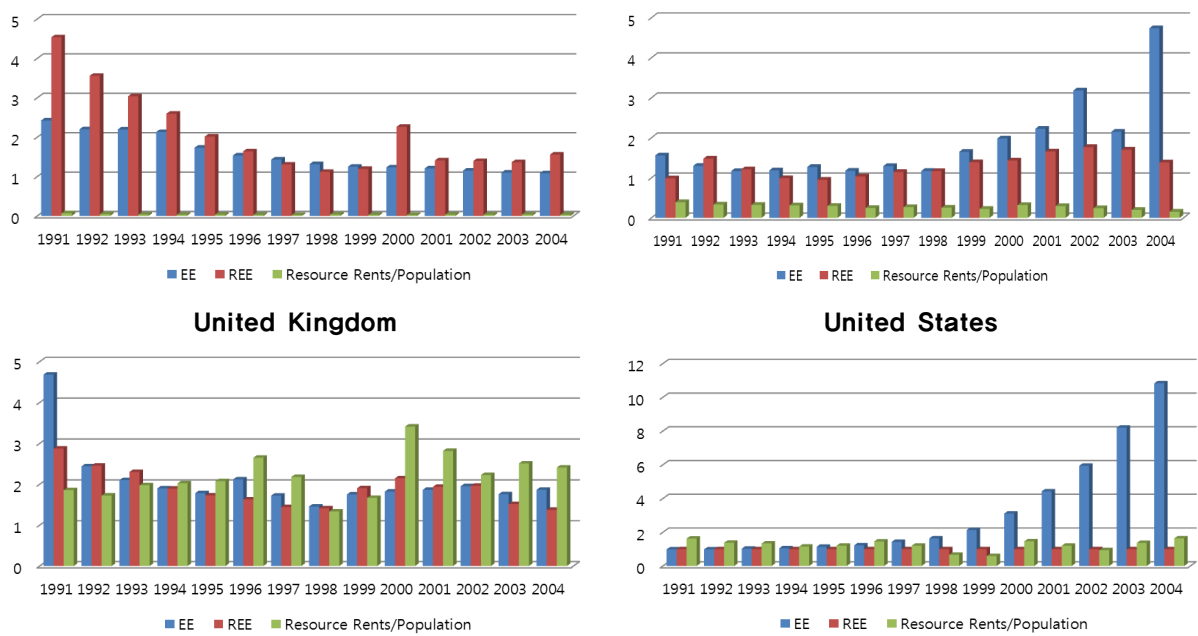

United States

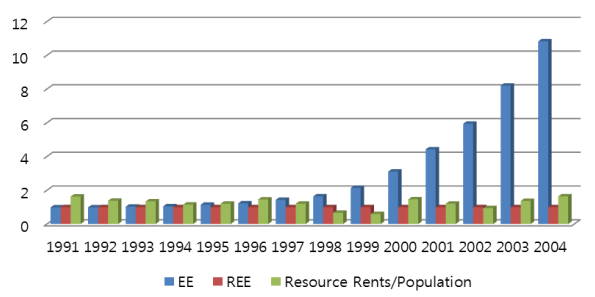

Notes: 1) The EE and REE represent the cross-industry average by country, respectively.

2) The EE figures are $1 / 10$ their actual sizes.

Sources: IEA, EU KLEMS and World Bank, author's calculation 
reflecting its status as a technological frontier with a market-friendly environment in energy use. Meanwhile, REE against the benchmark country (the U.S.) does not show clear improvement trends for Germany, France and the U.K. The REE of Japan increased slightly from 1994. The REE of Korea shows a downward trend since 1991 by and large. The level of REE in 2004 is high in Japan and Germany. The ratio of natural resources to population was high in the U.K. and the U.S., but Japan and Korea had a very low ratio, implying a scarcity of natural resources. Korea's trends seem exceptional. In contrast to other countries, both EE and REE fell over most of the whole sample period. Considering per capita resource rents are very low, the decline of energy efficiency may give a warning of the misallocation of energy resources.

Figure 2 displays the industry-level average of EE and REE for 22 industries over the period 1991 to 2004. There are sizable fluctuations in EE over the years. The fluctuations may result from heterogeneity in an industry's energy use and/or other country-specific factors. The trends of EE show a big improvement in the office, accounting and computing machinery, and radio, television and communication equipment industries. For other industries, EE has been changed just a bit or improved just a little over the sample period. The REE has increased in the two industries including tobacco, leather and footwear industries, while many others have decreased a little or have been stagnant with fluctuations over time.

Surprisingly, there has been a dramatic change in industries producing ICT equipments such as office, accounting and computing machinery, electrical machinery, and radio, television and communication equipment. In these industries, REE has declined sharply through the whole sample period while EE has risen since 1998. It implies that energy efficiency has been improved in ICT industries of the U.S., compared to that of other countries (particularly for the European countries), which is consistent to the findings: the European productivity slowdown is attributable to the slower emergence of the knowledge economy in Europe compared to the U.S. (van Ark, O'Mahony and Timmer, 2008). 
Figure 2: Energy Efficiency by Industry
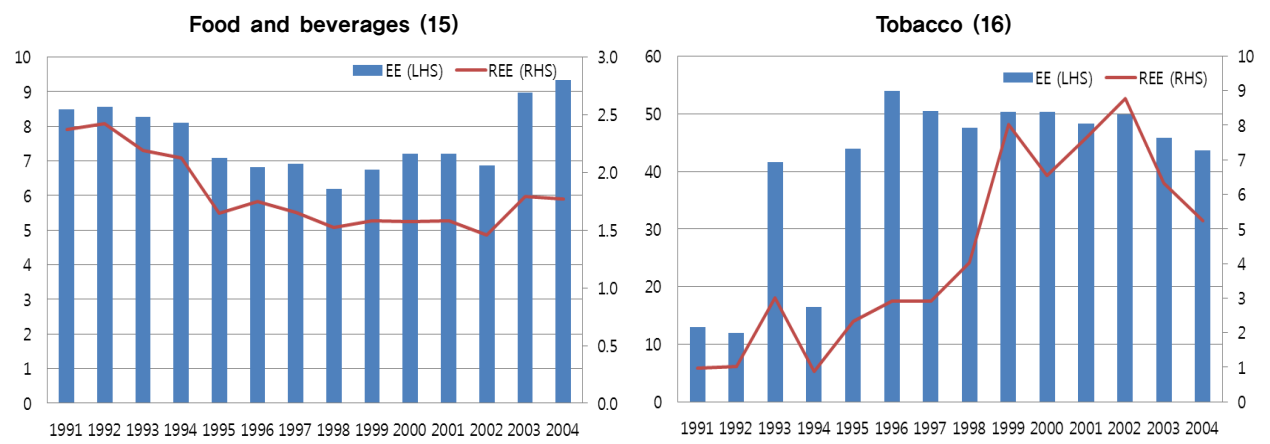

Textiles (17)

Wearing apparel (18)
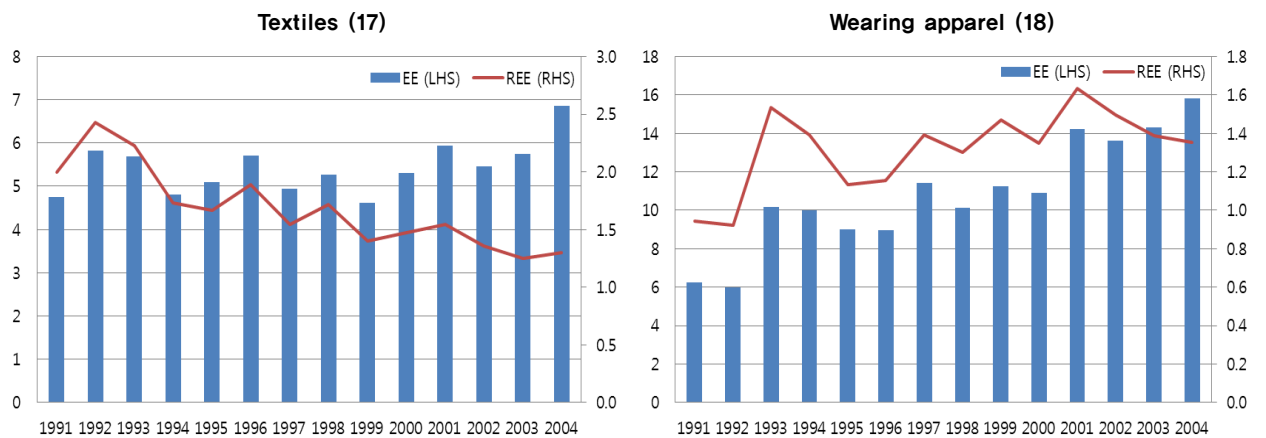

Leather and footwear (19)

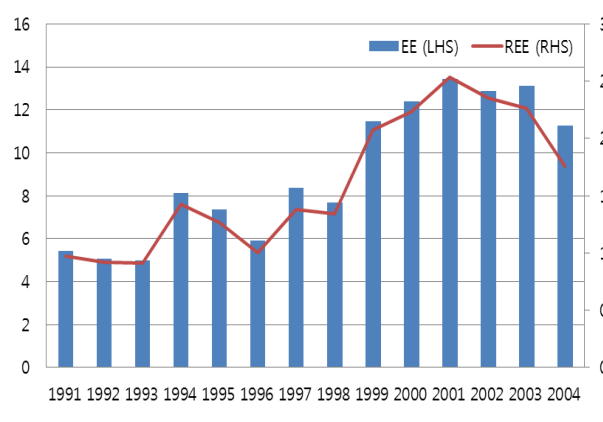

Wood and cork (20)

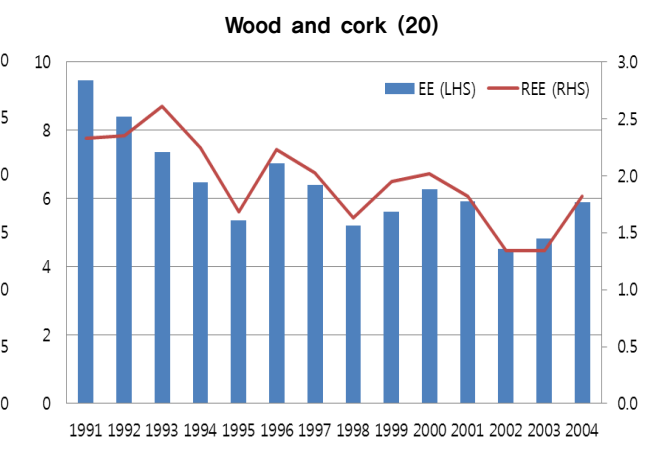

Pulp and paper (21)

Printing, publishing and reproduction (22)
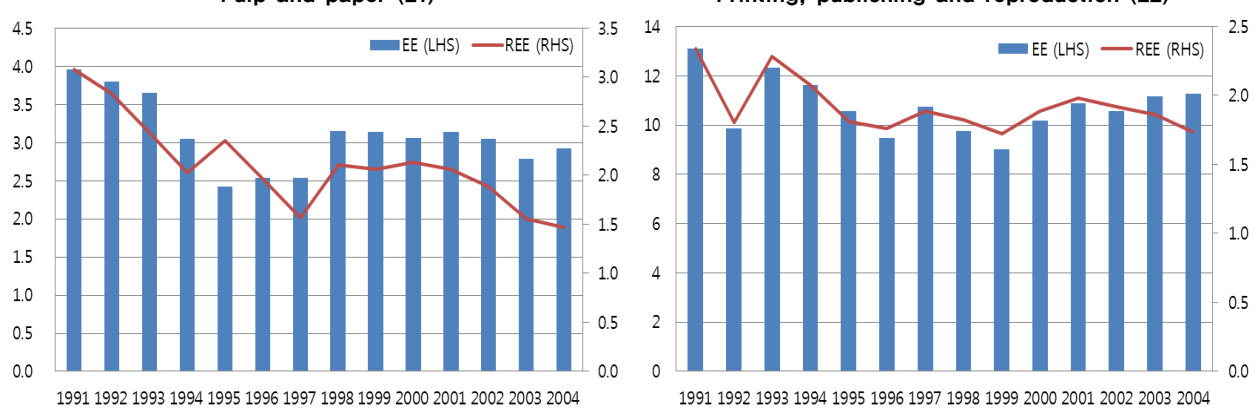
(Figure 2, continued)

Coke, refined petroleum products and nuclear fuel energy (23)

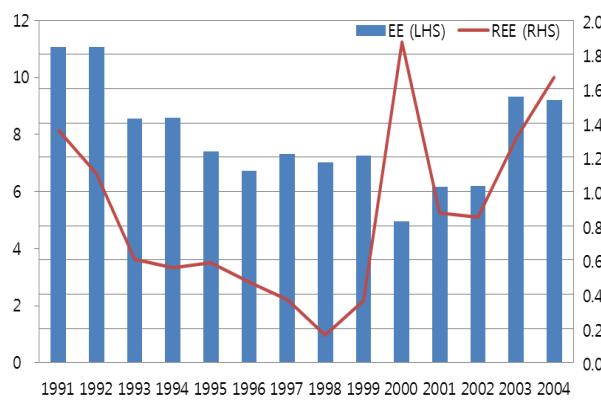

Rubber (25)

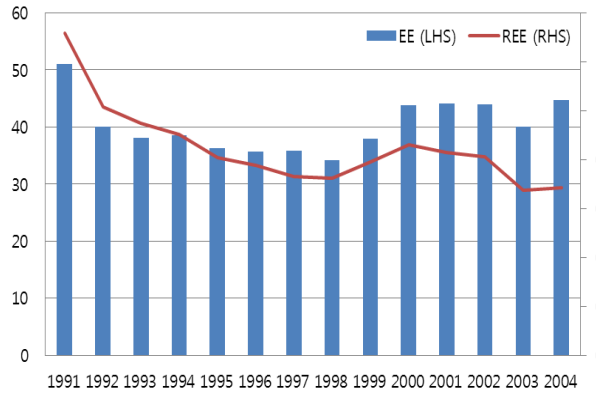

Basic metals (27)

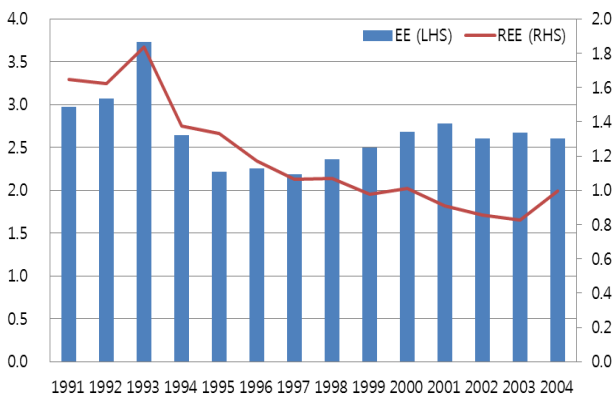

Machinery (29)

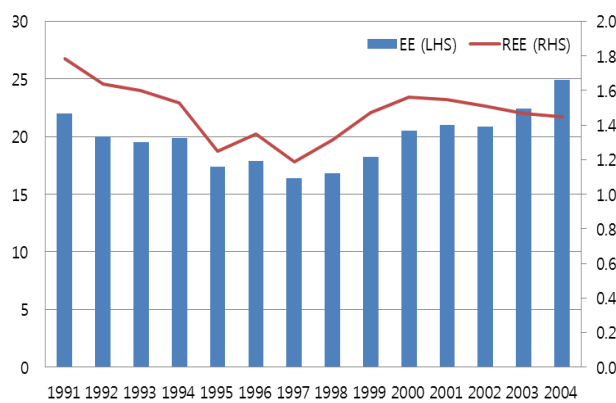

Chemicals (24)

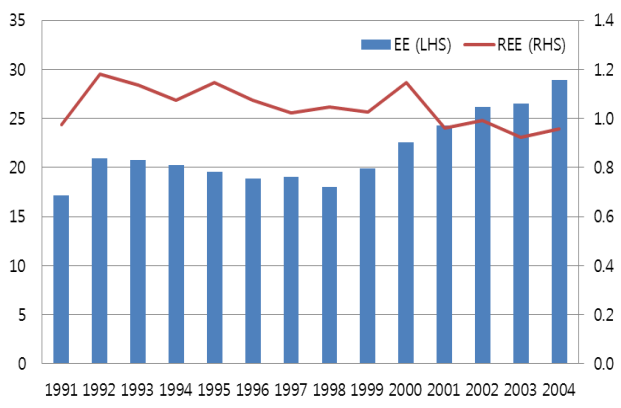

Non-metallic minerals (26)

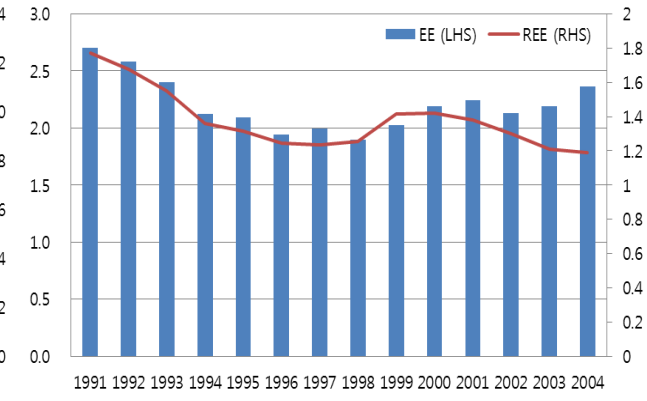

Fabricated metal (28)

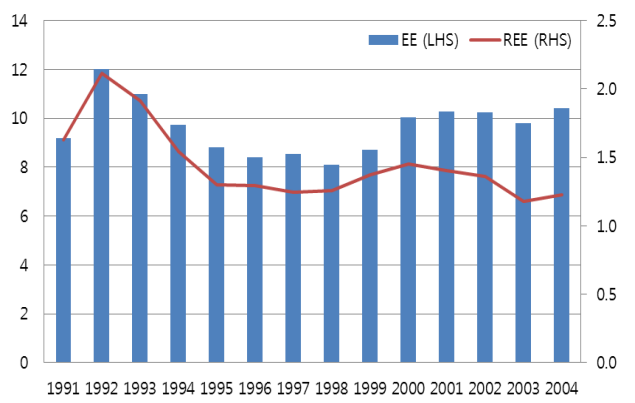

Office, accounting, and computing machinery (30)

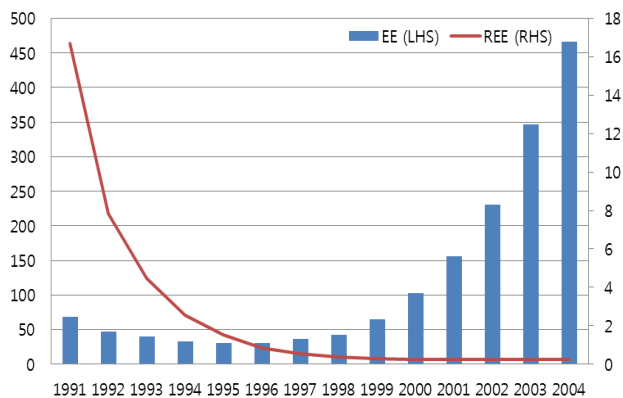


(Figure 2, continued)

Electrical machinery (31)

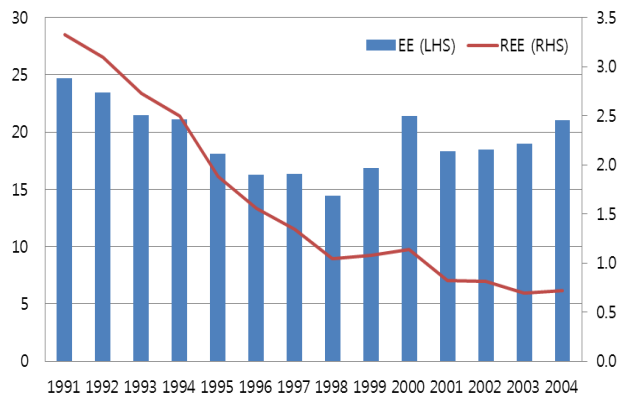

Medical, precision and optimal instruments (33)

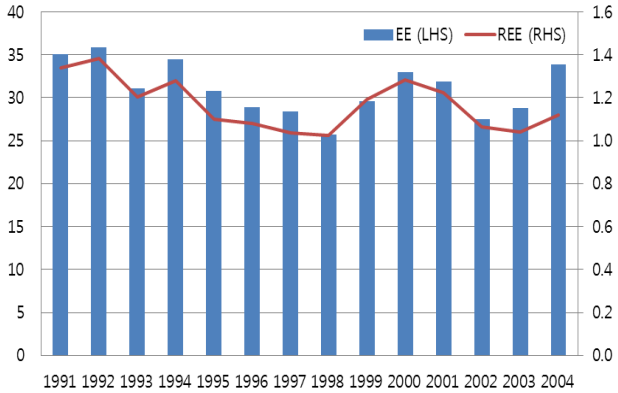

Other transport equipment (35)

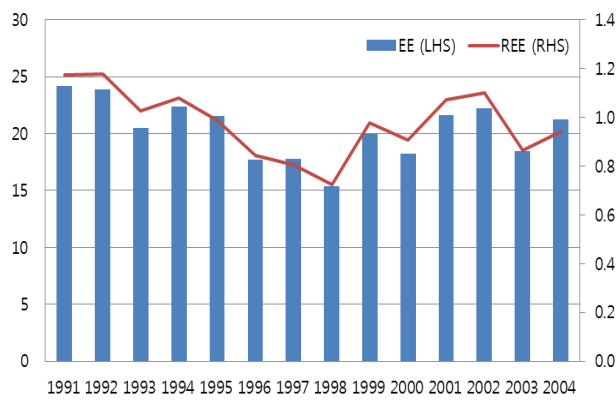

Radio, television and communication equipment (32)

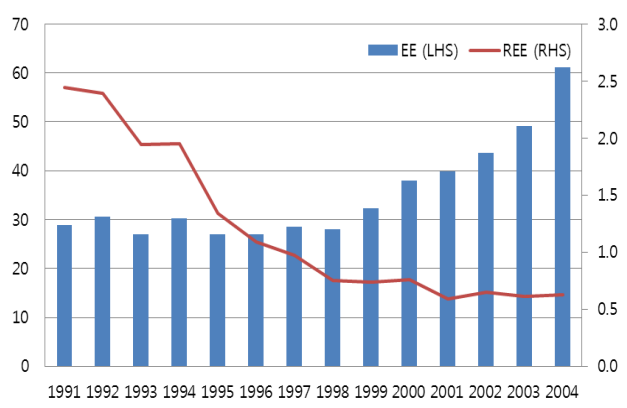

Motor vehicles, trailers and semi-trailers (34)

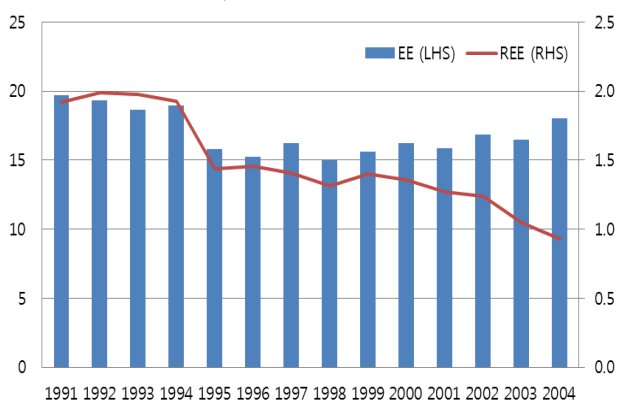

Furniture; manufacturing n.e.c. (36)

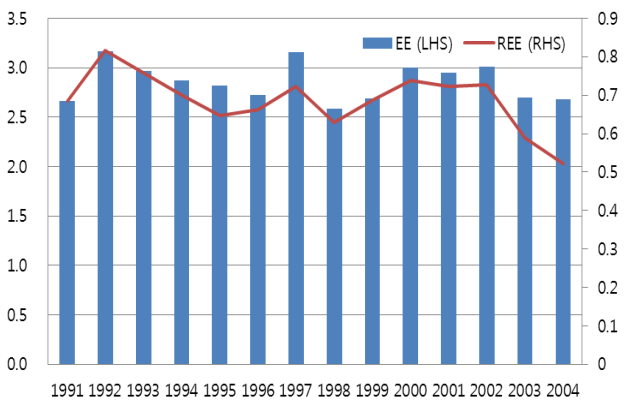

Note: The EE and REE represent the cross-country average by industry, respectively. Sources: IEA and EU KLEMS, author's calculation 


\section{Empirical Methodology}

Using the micro-level data for 1990-2005, we examine whether improvements in REE as well in EE facilitate the efficient allocation of resources and raises firm growth in terms of profits, sales and capital accumulation. This should be studied after controlling for country-by-country and industry-by-industry heterogeneity that may determine firm growth. In doing so, this provides a stronger causality test for the proposition that energy efficiency influences firm growth. We hypothesize that improvements in REE and EE raise capital accumulation as well as profits and sales.

\section{Empirical Model}

Let $g_{i, k, c, t}$ denote the firm growth in terms of profits, sales and capital accumulation between year $t$ and year $t+1$ for the observation of firm $i$, industry $k$, country $c$ and year $t$. The panel regression equation of firm growth $g_{i, k, c, t}$ is written as:

$$
\begin{aligned}
g_{i, k, c, t}= & \beta_{0}+\beta_{1} R E E_{k, c, t}\left(\operatorname{or} \beta_{1} E E_{k, c, t}\right)+W_{k, c, t}^{\prime} D_{k, c, t}+Z_{i, k, c, t}^{\prime} f_{i, k, c, t} \\
& +\sum_{k} \gamma_{k}+\sum_{c} \gamma_{c}+\sum_{t} \gamma_{t}+\varepsilon_{i, k, c, t}
\end{aligned}
$$

where $W_{k, c, t}$ and $Z_{i, k, c, t}$ are vectors controlling for other firm-level and industry-level traits. The parameter $f_{i, k, c, t}$ refers to the coefficient vector of $Z_{i, k, c, t}$ which contains total assets and the square of total assets, the ratios of cash and tangible fixed asset to total assets. Our specification of a set of firm-level variables $Z_{i, k, c, t}$ follows Bena and Ondko (2012). The squared-term of total assets controls for the U-shaped relation between size and growth predicted by Doms, Dunne, and Roberts (1994).6) We also control for the ability to finance a business by including cash and tangibility variables. The parameter $D_{k, c, t}$ refers to the

6) A theory on previous literature also suggested an inverted U-shaped relation between size and capital growth by the existence of sunk costs of capital capacity (Cabral, 1995). 
coefficient vector of $W_{k, c, t}$ which eliminates the country-specific difference for the demand for energy use. The control vector $W_{k, c, t}$ contains the log-ratio of industry $k$ 's energy use to total energy use in country $c,\left(\frac{\text { energy }_{k, c}}{\sum_{k} \text { energy }_{k, c}}\right)$; the interaction between $R E E_{k, c, t}$ (or $E E_{k, c, t}$ ) and country $c$ 's real GDP per capita, the interaction between $R E E_{k, c, t}$ ( or $E E_{k, c, t}$ ) and country $c$ 's natural resource rents per capita.

The sets of control vectors at the industry level and the firm level are constructed following firm-level studies on finance (Bena and Ondko, 2012; Claessens and Laeven, 2003). Finally, the regression controls for country- and industry-fixed effects. It includes industry $\left(\gamma_{k}\right)$, country $\left(\gamma_{c}\right)$ and year $\left(\gamma_{t}\right)$ dummies to control for time-invariant unobservable industry-and country-level factors affecting firm growth. The notation of $\varepsilon_{i, k, c, t}$ refers to the error term. The standard errors computed are robust to heteroskedasticity and country- and industry-level clustering.

Note that the coefficient $\beta_{1}$ of $R E E_{k, c, t}$ (or $E E_{k, c, t}$ ) is intended to capture the effect of within-country and within-sector differences in relative energy efficiency compared to the benchmark case. That is, we interpret $\beta_{1}$ as the effect of the improvement in REE or EE on firm growth.

\section{Data Construction}

We use the OSIRIS database ${ }^{7)}$ that provides firm-level financial and accounting information on the publicly-traded firms in two-digit (NACE) 22 manufacturing industries in 6 IEA countries including France, Germany, Japan, Korea, the U.K. and the U.S. during the whole sample period of 1990-2005.8) The 22 industries

7) OSIRIS is a fully integrated public company database and analytical information solution produced by Bureau van Dijk Electronic Publishing, SA (BvDEP). Working with specialist data providers from around the world, OSIRIS provides financials, ownership, news, ratings, earnings and stock data for the world's publicly quoted companies, including banks and insurance firms from over 130 countries.

8) The sample countries are restricted to 6 IEA countries of the 18 IEA countries that provide industry-level energy intensity. Other countries are dropped since the OSIRIS data for such countries provides less than 300 observations. 
and their two-digit NACE codes are as follows: Food and beverages (15), Tobacco (16), Textiles (17), Wearing apparel (18), Leather and footwear (19), Wood and cork (20), Pulp and Paper (21), Printing, publishing and reproduction (22), Coke, refined petroleum products and nuclear fuel (23), Chemicals (24), Rubber (25), Non-metallic minerals (26), Basic metals (27), Fabricated metal (28), Machinery (29), Office, accounting, and computing machinery (30), Electrical machinery (31), Radio, television and communication equipment (32), Medical, Precision and optimal instruments (33), Motor vehicles, trailers and semi-trailers (34), Other transport equipment (35), Furniture; manufacturing n.e.c. (36). This database provides detailed firm-level information such as balanced sheet items including sales, profits, capital expenditure, total assets and cash among others. We analyze the impact of REE or EE on firm growth in terms of the growth rate between year $t$ and year $t+1$ in each firm.

We in turn discuss how to measure the industry-level REE and EE. We use the databases served by EU KLEMS and IEA in order to construct the industry-level energy intensity of the sample countries. This is usually defined as the ratio of real energy uses to real value added as the inverse of energy efficiency. The EU KLEMS database ${ }^{9)}$, which includes data for industrial growth accounting of $\mathrm{EU}$ members and some other countries, provides annual time series of industry-level real value added and the indexes of real energy uses with a base year of 1995, and covering 1970 to 2005.10) Therefore, we select the sample period of 1990 to 2005 based on the availability of related data. ${ }^{11)}$

9) EU KLEMS provides data which are required to produce sector total factor productivity of an economy. The database covers 72 sectors of 26 EU members (except Bulgaria, Croatia, and Rumania) and 5 non-EU members (Australia, Canada, Japan, Korea, and the U.S.). The 2008 March release of the EU KLEMS database includes classified intermediates such as energy, materials, and services.

10) EU KLEMS database is distributed by three releases; 2007 March release, 2008 March release, and 2009 November release (updated at 2011 March). Among them, 2009 Nov. release is the newest database ranging 1970 to 2007 but does not provide details of intermediate inputs such as material, energy, and service. Whereas, 2008 March release ranging 1970 to 2005 includes the details of input data. Since this research requires energy input data, we adopt 2008 March release of EU KLEMS.

11) More recent data beyond our sample period are not available. We double checked this issue through the related literature (e.g., Vogit, Cian, Schymura and Verdolini, 2014). 
Table 1: Manufacturing Sectors in Energy Balance (IEA) and EU KLEMS Database

\begin{tabular}{|c|c|c|}
\hline \multirow{2}{*}{ Energy Balance } & \multicolumn{2}{|r|}{ EU KLEMS } \\
\hline & Code & Industry description \\
\hline Food and tobacco & $15-16$ & Food, beverages, and tobacco \\
\hline Textile and leather & $17-19$ & Textiles, wearing apparel, leather, and footwear \\
\hline Wood and wood products & 20 & Wood and cork \\
\hline Paper, pulp and printing & $21-22$ & Pulp, paper, printing, publishing and reproduction \\
\hline Chemical and Petrochemical & $23-25$ & $\begin{array}{l}\text { Coke, refined petroleum products, nuclear fuel, } \\
\text { chemical, and rubber }\end{array}$ \\
\hline Non-metallic mineral & 26 & Non-metallic minerals \\
\hline Iron and steel & \multirow{2}{*}{$27-28$} & \multirow{2}{*}{ Basic metal and fabricated metal products } \\
\hline Non-ferrous metal & & \\
\hline \multirow[b]{2}{*}{ Machinery } & 29 & Machinery \\
\hline & $30-33$ & $\begin{array}{l}\text { Office, accounting, computing machinery, electrical machinery } \\
\text { radio, television and communication equipment } \\
\text { medical, precision and optimal instruments }\end{array}$ \\
\hline Transport equipment & $34-35$ & $\begin{array}{l}\text { Motor vehicles, trailers, semi-trailers, } \\
\text { and Other transport equipment }\end{array}$ \\
\hline Non-specified & 36 & Furniture; manufacturing n.e.c. \\
\hline
\end{tabular}

Sources: IEA, EU KLEMS

For the calculation of the energy intensity, we need real energy uses in term of an energy unit such as the tons of oil equivalent. However, EU KLEMS provides only indexes of real energy use instead of the real quantity of energy use. If we wish to know the quantities of industrial energy use in a reference year, a series of industrial energy use is calculated by applying the index of energy use in EU KLEMS. This calculation involves several steps. First, the quantities of industrial real energy use of the 2005 Energy Balance from IEA are adopted as references for real energy use in year 2005.12) Unfortunately, the EU KLEMS and Energy Balance are constructed using different industrial definitions from each other (see

12) As the real quantity of reference year can reflect the relative price system of the year among industries, great caution is necessary in calculating the rest of the real time-series data. In this data construction work, there is no concern about additional distortion by selecting a reference year because we construct level data from the time series of the index. 
Table 1).13) NACE rev.1, the industrial definition used in EU KLEMS, is overall more disaggregated than the industries in the Energy Balance. In order to match the industrial codes, we collect the industry-level energy uses in 2005 of Energy Balance and redistribute them on the basis of NACE rev.1. For disaggregation, nominal energy uses in EU KLEMS are applied as weights.

Second, we reproduce the quantities of industrial energy uses for the rest of years from the real energy uses in year 2005 by applying the index of industrial energy use of EU KLEMS. Third, the real value added of EU KLEMS is measured in the currencies of industrial countries have different purchasing power. We therefore reevaluate the real value added at purchasing power parity (PPP) exchange rates in order to ensure international comparability. ${ }^{14)}$ The sample is restricted to firms whose asset value is more than US\$500,000. Otherwise, the sample would have a bias due to the disparity in average firm size across countries. After selecting more than 300 observations of within-country OSIRIS data, six countries and 22 industries are finally chosen.

Regarding the data cleaning, the procedure is in line with the previous research utilizing the OSIRIS database. First, we drop the bottom and top percentile of year-on-year changes in total assets in order to avoid the influence of extreme events such as mergers, acquisitions or spinoffs. We deflate all financial variables by using the U.S. CPI. Finally, we delete the top 1-percentile and the bottom 1-percentile of firm growth in terms of capital accumulation as well as profits and sales from the sample. The number of firm-industry-country observations used in the panel regression analysis becomes 8,920 observations for profits, 8,826 observations for sales, and 7,557 observations for capital accumulation, respectively. Table 2 presents the summary statistics of OSIRIS firm-level variables.

13) Energy Balance (IEA) classifies manufacturing into 11 industries while EU KLEMS adopts the industrial classification of NACE rev.1, which classifies manufacturing into 22 industries.

14) The annual country-level PPP exchange rates are collected from the website of Bank of Korea (ecos.bok.or.kr). 


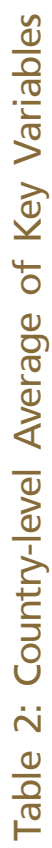

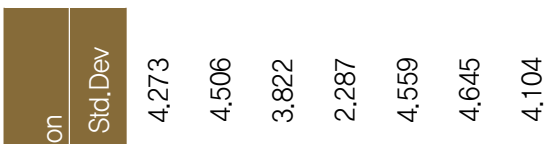

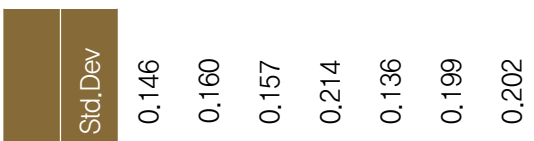

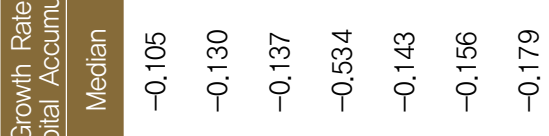

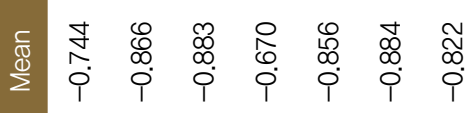

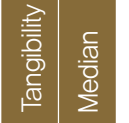

蕉

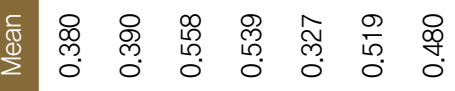

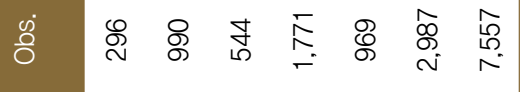

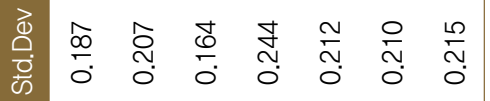

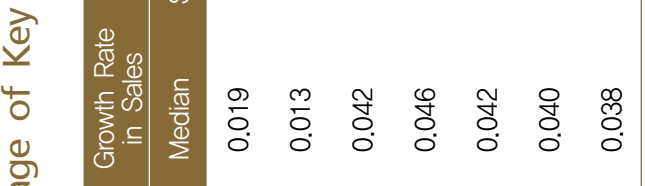

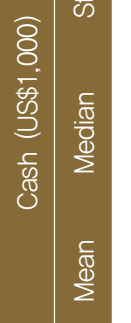

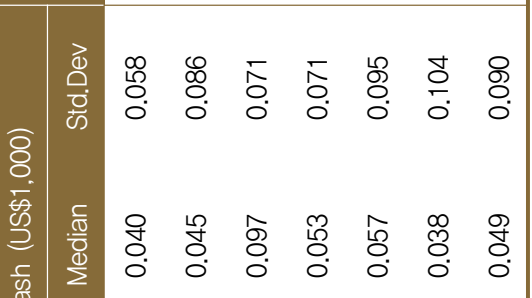

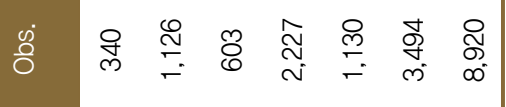

离

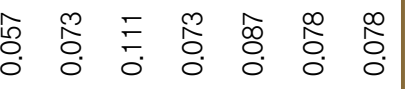

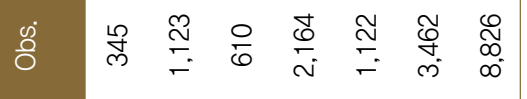

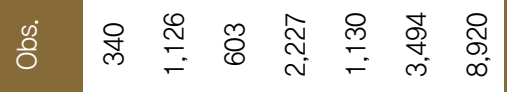

离

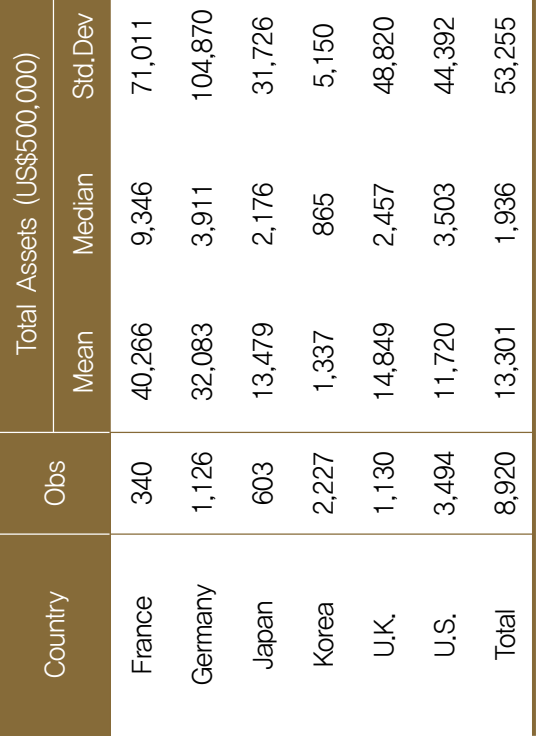

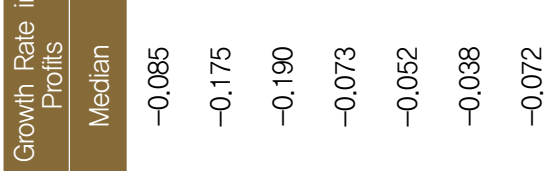

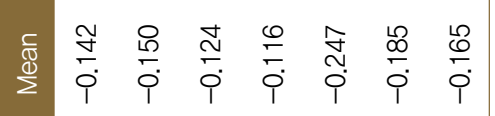

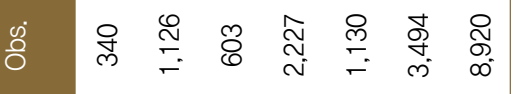

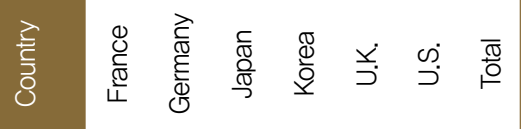




\section{Estimation Results}

Table 3 provides the estimation results of the panel regression of equation (3) in Section $\mathbb{I I}$, where dependent variables are the growth rates of profits, sales, and capital accumulation. We test whether improvements in the traditional measure of energy efficiency (EE) or a relative measure of energy efficiency (REE) raise firm growth. Model I and Model II in Table 3 show the results of the firms' profit growth. Note that we are interested in testing the main null hypothesis that the coefficient $\beta_{1}$ of EE or REE is zero which cannot be rejected. EE has a significant inverse relationship with profit growth in Model I, indicating that the efficient allocation of energy resources hinders the firms' profit growth. However, this result may be biased because the measure overlooks the heterogeneity in the industry's naturally own energy demand. At the same time, EE imposes large weights on ICT industries in which the U.S. firms earned much higher profits in general through the sample period.

In contrast, REE, for which the heterogeneity in the industry's naturally own energy demand was controlled, has a significantly positive impact on the firms' profit growth in Model II. This suggests that improvements in REE raise firms' profit growth. The coefficient of REE $\times$ GDP per capita is significantly negative, implying that the marginal impact of energy efficiency diminishes as a nation becomes wealthier. The coefficient of REE $\times$ Resources per capita is positive; the more abundant the natural resources, the higher the opportunity to save energy costs through efficient allocation of energy. The coefficients of Cash and Tangibility are also positive; high-level cash and tangible asset holding firms have attained a higher profit growth.

In Model III and Model $\mathrm{V}$ of Table 3, the estimated coefficient $\beta_{1}$ is significantly positive with both EE and REE. This result confirm that improvements in energy efficiency increase the sales in firms. Through Model II and Model IV, it is also verified that improvements in REE may raise sales as well as profits.

Model V and Model VI show whether improvements in energy efficiency raise capital accumulation of firms by increasing their capital expenditure. Capital expenditure is in general implemented by a firm to acquire or upgrade physical assets such as property, industrial buildings or equipment. For both the EE 
Table 3: Estimation Results of Panel Regression for Six Sample Countries

\begin{tabular}{|c|c|c|c|c|c|c|}
\hline \multirow{2}{*}{ Dependent Variable } & \multicolumn{2}{|c|}{ Growth in Profits } & \multicolumn{2}{|c|}{ Growth in Sales } & \multicolumn{2}{|c|}{$\begin{array}{l}\text { Growth in } \\
\text { Capital Accumulation }\end{array}$} \\
\hline & Model I & Model II & Model III & Model IV & Model V & Model VI \\
\hline \multirow[t]{2}{*}{ REE } & & $0.882^{* * *}$ & & $0.074^{* *}$ & & $0.563^{* *}$ \\
\hline & & $(0.144)$ & & $(0.032)$ & & $(0.267)$ \\
\hline \multirow[t]{2}{*}{ EE } & $-0.035^{* *}$ & & $0.009^{* *}$ & & $0.168^{* *}$ & \\
\hline & $(0.015)$ & & $(0.004)$ & & $(0.069)$ & \\
\hline \multirow[t]{2}{*}{ REE $\times$ GDP per capita } & & $-0.079^{* * *}$ & & -0.004 & & $-0.050^{* *}$ \\
\hline & & $(0.015)$ & & $(0.003)$ & & $(0.023)$ \\
\hline \multirow[t]{2}{*}{ REE $\times$ Resources per capita } & & $0.007^{* * *}$ & & $0.004^{* * *}$ & & 0.012 \\
\hline & & $(0.000)$ & & $(0.001)$ & & $(0.018)$ \\
\hline \multirow[t]{2}{*}{ EE $\times$ GDP per capita } & $0.003^{* *}$ & & $-0.001^{* *}$ & & $-0.014^{* *}$ & \\
\hline & $(0.001)$ & & $(0.000)$ & & $(0.006)$ & \\
\hline \multirow[t]{2}{*}{ EE Resources per capita } & $-0.001^{* * *}$ & & 0.000 & & $0.003^{* * *}$ & \\
\hline & $(0.000)$ & & $(0.000)$ & & $(0.001)$ & \\
\hline \multirow[t]{2}{*}{ Energy / Total Energy } & 0.008 & 0.005 & $-0.009^{* * *}$ & $-0.009^{* * *}$ & -0.032 & -0.059 \\
\hline & $(0.011)$ & $(0.025)$ & $(0.002)$ & $(0.003)$ & $(0.088)$ & $(0.099)$ \\
\hline \multirow[t]{2}{*}{ Total Assets } & -0.294 & -0.314 & $-0.074^{*}$ & $-0.074^{*}$ & $0.839^{* * *}$ & $0.851^{* * *}$ \\
\hline & $(0.361)$ & $(0.368)$ & $(0.038)$ & $(0.039)$ & $(0.307)$ & $(0.300)$ \\
\hline \multirow[t]{2}{*}{$(\text { Toal Assets) })^{2}$} & 0.018 & 0.019 & $0.003^{*}$ & 0.003 & $-0.028^{* *}$ & $-0.028^{* *}$ \\
\hline & $(0.021)$ & $(0.022)$ & $(0.002)$ & $(0.002)$ & $(0.014)$ & $(0.013)$ \\
\hline \multirow[t]{2}{*}{ Cash } & $0.604^{* * *}$ & $0.590^{* *}$ & $0.209^{* * *}$ & $0.207^{* * *}$ & 0.342 & 0.328 \\
\hline & $(0.231)$ & $(0.248)$ & $(0.045)$ & $(0.044)$ & $(0.316)$ & $(0.283)$ \\
\hline \multirow[t]{2}{*}{ Tangibility } & $0.398^{* *}$ & $0.421^{* *}$ & $0.167^{* * *}$ & $0.170^{* * *}$ & -0.324 & -0.315 \\
\hline & $(0.199)$ & $(0.189)$ & $(0.025)$ & $(0.026)$ & $(0.532)$ & $(0.534)$ \\
\hline \multirow[t]{2}{*}{ Constant } & 0.762 & 0.693 & 0.244 & 0.231 & $-6.940^{* * *}$ & $-7.026^{* * *}$ \\
\hline & (1.520) & (1.508) & $(0.184)$ & $(0.177)$ & (1.663) & (1.649) \\
\hline R-squared & 0.01 & 0.01 & 0.10 & 0.10 & 0.02 & 0.02 \\
\hline Obs. & 8,920 & 8,920 & 8,826 & 8,826 & 7,557 & 7,557 \\
\hline
\end{tabular}

Notes: 1) $*, * *$, and $* * *$ denote significance at the $10 \%, 5 \%$, and $1 \%$ levels, respectively, based on standard errors.

2) Standard errors reported inside parentheses below the corresponding coefficients are robust to heteroscedasticity. 
and REE measures, the null hypothesis is rejected at a significant level, implying that firms with more energy-efficient capital deployment are more likely to reallocate resources for energy inputs to long-term capital raising. Among the control variables, total assets and the square of total assets are statistically significant, and consistent with the prediction of an inverted U-shaped relation between size and capital growth based on some degree of sunkness of capital capacity (Cabral, 1995).

As mentioned in Section $\mathbb{I}$, Korea has fewer natural resources, and shows an exceptional trend; both EE and REE have fallen over the period. This may have resulted from the misallocation of energy resources due to regulations on energy prices, leading to dampening firms' incentive to enhance energy efficiency. For verifying the difference in growth channels, we ran the panel regression on growth of the Korean firms. Table 4 provides the estimation results of the Korean sample where the dependent variables are growth rate of profits, sales and capital accumulation. We relaxed our restriction on asset size in order to obtain a sufficient sample. Since Korea has been particularly sensitive to external shocks, which led to capital outflows and rapid currency depreciation during the Asian financial crisis from 1997 to 1998, we added the Asian crisis dummy to the regression equation (3) in Section III.

Shown in Model I, Model III and Model V of Table 4, the traditional measure, $\mathrm{EE}$ is insignificant in explaining firm growth in all aspects. Even controlling for the heterogeneity in the industry's own energy demand, REE is insignificant in explaining both profits and sales, despite having a significantly positive impact on capital accumulation through Model II, Model IV and Model VI. These results indicate that Korea has a weak growth channel of energy efficiency to firms. From Model I to Model $\mathrm{V}$, the coefficient of the Asian crisis dummy turns out to be significantly positive. This can be attributable to surviving export-oriented firms which had grown faster during the crisis owing to the Korean currency depreciation against the U.S. dollar.

As Korea has few natural resources and most raw materials needed for manufacturing are imported, the results in Table 4 give us an insight on the energy policy for the country. Considering tight natural resource constraints in Korea, the efficient use of energy would be much more important for firms in Korea than those in other countries. 
Table 4: Estimation Results of Panel Regression for Korea

\begin{tabular}{|c|c|c|c|c|c|c|}
\hline \multirow{2}{*}{ Dependent Variable } & \multicolumn{2}{|c|}{ Growth in Profits } & \multicolumn{2}{|c|}{ Growth in Sales } & \multicolumn{2}{|c|}{$\begin{array}{c}\text { Growth in } \\
\text { Capital Accumulation }\end{array}$} \\
\hline & Model I & Model II & Model III & Model IV & Model V & Model Vl \\
\hline \multirow[t]{2}{*}{ REE } & & 0.160 & & 0.002 & & $0.858^{* *}$ \\
\hline & & $(0.168)$ & & (0.058) & & $(0.370)$ \\
\hline \multirow[t]{2}{*}{ EE } & -0.003 & & -0.007 & & -0.500 & \\
\hline & $(0.034)$ & & $(0.008)$ & & $(0.076)$ & \\
\hline \multirow[t]{2}{*}{ REE $\times$ GDP per capita } & & -0.027 & & -0.000 & & -0.088 \\
\hline & & $(0.024)$ & & $(0.010)$ & & $(0.071)$ \\
\hline \multirow[t]{2}{*}{ REE $\times$ Resources per capita } & & -0.014 & & 0.000 & & 0.008 \\
\hline & & $(0.012)$ & & $(0.006)$ & & $(0.048)$ \\
\hline \multirow{2}{*}{ EEXGDP per capita } & 0.000 & & 0.000 & & 0.011 & \\
\hline & $(0.004)$ & & $(0.010)$ & & $(0.010)$ & \\
\hline \multirow[t]{2}{*}{ EEXResources per capita } & -0.000 & & -0.000 & & 0.005 & \\
\hline & $(0.001)$ & & $(0.000)$ & & $(0.005)$ & \\
\hline \multirow[t]{2}{*}{ Energy / Total Energy } & 0.099 & $0.128^{* *}$ & -0.027 & -0.010 & -0.154 & -0.206 \\
\hline & $(0.084)$ & $(0.052)$ & $(0.024)$ & $(0.019)$ & $(0.217)$ & $(0.147)$ \\
\hline \multirow[t]{2}{*}{ Total Assets } & 0.027 & 0.026 & $0.017^{* * *}$ & $0.017^{* * *}$ & $-0.235^{* * *}$ & $-0.245^{* * *}$ \\
\hline & $(0.024)$ & $(0.024)$ & $(0.005)$ & $(0.006)$ & $(0.043)$ & $(0.043)$ \\
\hline \multirow[t]{2}{*}{$(\text { Toal Assets) })^{2}$} & $-0.006^{* *}$ & $-0.006^{* *}$ & $-0.004^{* * *}$ & $-0.004^{* * *}$ & 0.008 & 0.009 \\
\hline & $(0.003)$ & $(0.003)$ & $(0.000)$ & $(0.000)$ & $(0.005)$ & $(0.005)$ \\
\hline \multirow[t]{2}{*}{ Cash } & 0.070 & 0.074 & $0.105^{* * *}$ & $0.123^{* * *}$ & 0.125 & 0.140 \\
\hline & $(0.221)$ & $(0.216)$ & $(0.021)$ & $(0.028)$ & $(0.196)$ & $(0.205)$ \\
\hline \multirow[t]{2}{*}{ Tangibility } & -0.180 & -0.172 & 0.006 & 0.000 & $-0.187^{*}$ & $-0.222^{*}$ \\
\hline & $(0.116)$ & $(0.115)$ & $(0.030)$ & $(0.030)$ & $(0.122)$ & $(0.117)$ \\
\hline \multirow[t]{2}{*}{ Asian Crisis } & $0.261^{* * *}$ & $0.276^{* * *}$ & $0.172^{* * *}$ & $0.192^{* * *}$ & 0.162 & 0.043 \\
\hline & $(0.075)$ & $(0.070)$ & $(0.041)$ & $(0.037)$ & $(0.296)$ & $(0.215)$ \\
\hline \multirow[t]{2}{*}{ Constant } & 0.768 & $0.902^{* * *}$ & -0.109 & -0.014 & -0.581 & -0.652 \\
\hline & $(0.463)$ & $(0.285)$ & $(0.134)$ & $(0.109)$ & (1.194) & $(0.826)$ \\
\hline R-squared & 0.04 & 0.04 & 0.22 & 0.24 & 0.02 & 0.03 \\
\hline Obs. & 9,773 & 9,773 & 8,796 & 8,796 & 7,635 & 7,635 \\
\hline
\end{tabular}

Notes: 1) $* * *$, and $* * *$ denote significance at the $10 \%, 5 \%$, and $1 \%$ levels, respectively, based on standard errors.

2) Standard errors reported inside parentheses below the corresponding coefficients are robust to heteroscedasticity. 


\section{Conclusion}

This paper highlights the importance of understanding the role of the efficient use of energy inputs for economic growth. Using micro-level data, we attempted to identify a relation between energy efficiency and firm growth over six countries (France, Germany Japan, Korea, the U.K., and the U.S.) and 22 manufacturing industries during the period of 1990-2005. We developed a new energy efficiency measure reducing distortions derived from variations by industry for each country. We then ran a panel regression of firm growth in a country- and industry-specific relative energy efficiency (REE) measure to the corresponding industrial sector in the benchmark country (the U.S.) in addition to the traditional energy efficiency measure (EE) using only the inverse of energy intensity, after controlling for several firm, industry, and country variables.

We find that REE and EE may have somewhat different impacts on firm growth in terms of profits, although improvements in both REE and EE have a positive effect on the growth rate of sales and capital accumulation. According to the estimation results, the impact of an improvement in REE increases the profitability of firms, whereas improvement in EE has a negative effect. This result indicates that the REE index needs to be considered in addition to an EE index in judging the impact of improvements in energy efficiency on firms' growth.

In addition, we find using Korean panel data only that both REE and EE have no statistically significant impact on firms' profits and sales in Korea despite having a positive impact on their capital growth, implying that the efficient use of energy inputs has made a smaller contribution to firm growth. This may be partly attributable to regulations on energy prices under Korea's tight natural energy resources constraints. 


\section{References}

Ang, B., and F. Zhang (2000), "A Survey of Index Decomposition Analysis in Energy and Environmental Studies," Energy, Vol. 25, pp. 1149-1176.

Ayres, R., H. Turton, and T. Casten (2007), "Energy Efficiency, Sustainability and Economic Growth," Energy, Vol. 32, pp. 634-648.

Azevedo, L., M. Sonnberger, B. Thomas, G. Morgan, and O. Renn (2012), "Developing Robust Energy Efficiency Policies While Accounting for Consumer Behavior," International Risk Governance Council (IRGC) Report.

Beck, T., A. Demirguc-Kunt, L. Laeven, and R. Levine (2008), "Finance, Firm Size, and Growth," Journal of Money, Credit and Banking, Vol. 40, pp. 1379-1405.

Bena, J., and P. Ondko (2012), "Financial Development and the Allocation of External Finance," Journal of Empirical Finance, Vol. 19(1), pp. 1-25.

Borenstein, S. (2013), “A Microeconomic Framework for Evaluating Energy Efficiency Rebound and Some Implications," NBER Working Paper, No. 19044.

Cabral, L. M. (1995), "Sunk Costs, Firm Size and Firm Growth," Journal of Industrial Economics, Vol. 43(2), pp. 161-172.

Doms, M., T. Dunne, and M. Roberts (1995), "The Role of Technology Use in the Survival and Growth of Manufacturing Plants," International Journal of Industrial Organization, Vol. 13(4), pp. 523-542.

Durnev, A., R. Morck, and B. Yeung (2004), "Value-enhancing Capital Budgeting and Firm Specific Stock Return Variation," Journal of Finance, Vol. 59(1), pp. 65-105.

Duro, J., V. Alcántara, and E. Padilla (2010), "International Inequality in Energy Intensity Levels and the Role of Production Composition and Energy Efficiency: An Analysis of OECD Countries," Ecological Economics, Vol. 40, pp. 637-644. 
Fisman, R., and I. Love (2007), "Financial Dependence and Growth Revisited," Journal of the European Economic Association, Vol. 5, pp. 470-479.

Greening, L., D. Greene, and C. Difiglio (2000), "Energy Efficiency and Consumption - The Round Effect - A Survey," Energy Policy, Vol. 28, pp. $389-401$.

Jorgenson, D. (1986), "The Great Transition: Energy and Economic Change," Energy Journal, Vol. 7(3), pp. 1-13.

Inhaber, H., and H. Saunders (1994), "Road to Nowhere: Energy Conservation Often Backfires and Leads to Increased Consumption," The Sciences, Vol. 34(6), pp. 20-25.

Medlock III, K., and R. Soligo (2001), "Economic Development and End-Use Energy Demand," Energy Journal, Vol. 22(2), pp. 77-105.

Mulder, P., and H. Groot (2012), "Structural Change and Convergence of Energy Intensity across OECD Countries," Energy Economics, Vol. 34, pp. 1910-1921.

Murillo-Zamorano, L. (2005), "The Role of Energy in Productivity Growth: A Controversial Issue?" The Energy Journal, Vol. 26(2), pp. 69-88.

Rajan, R., and L. Zingales (1998), "Financial Dependence and Growth," American Economic Review, Vol. 88(3), pp. 559-586.

Roca, J., and V. Alcantara (2001), "Energy Intensity, CO2 Emissions and the Environmental Kuznets Curve: The Spanish Case," Energy Policy, Vol. 29(7), pp. 553-556.

Schurr, S. (1982), "Energy Efficiency and Productive Efficiency: Some Thoughts Based on American Experience," Energy Journal, No. 3, pp. 3-14.

Sorrel, S. (2009), "Jevons' Paradox Revisited: The Evidence for Backfire from Improved Energy Efficiency," Energy Policy, Vol. 37, pp. 1456-1469.

Stern, D. (2011), "The Role of Energy in Economic Growth," Ecological Economics Reviews, Vol. 1219, pp. 26-51. 
Van Ark, B., M. O’Mahony, and M. Timmer (2008), "The Productivity Gap between Europe and the U.S.: Trends and Causes," Journal of Economic Perspectives, Vol. 22(1), pp. 25-44.

Voigt, S., E. Cian, M. Schymura, and E. Verdolini (2014), "Energy Intensity Developments in 40 Major Economies: Structural Change or Technology Improvement?" Energy Economics, Vol. 41(C), pp. 47-62.

Wang, C. (2013), "Changing Energy Intensity of Economies in the World and Its Decomposition," Energy Economics, Vol. 40, pp. 637-644.

Warr, B., and R. Ayres (2010), "Evidence of Causality between the Quantity and Quality of Energy Consumption and Economic Growth," Energy, Vol. 35, pp. 1688-1693. 


\section{<Abstract in Korean>}

\section{에너지 효율성과 기업성장}

\section{최봉석*, 박우영**, 유복근***}

본 연구는 미시자료를 이용하여 1990 2005년간 6개국(프랑스, 독일, 일본, 한국, 영국, 미국)의 22 개 제조업을 대상으로 에너지 효율성과 기업성장 과의 인과관계를 분석하였다. 동 분석을 위해 본고에서는 전통적인 에너지 효율성 지표(EE measure) 이외에 미국의 산업별 에너지 효율성에 대한 상대적인 비율로 표시되는 소위 상대적 에너지 효율성 지표(REE measure)를 새로 만들어 사용하였다.

분석 결과, 기업의 매출액과 자본축적 면에서는 두 지표가 동일하게 정 $(+)$ 의 영향을 주나 수익성에는 두 지표의 영향이 상이한 것으로 나타났다. 이는 에너지 효율성과 기업성장과의 관계 분석 시 두 가지 지표를 동시에 고려할 필요가 있음을 시사한다. 한편 우리나라 기업만을 대상으로 별도로 분석한 결과에서는 두 지표 모두 기업의 매출액 및 수익성과의 관련성이 적은 것으로 나타났다.

핵심주제어: 에너지 효율성, 에너지 집약도, 경제성장, 기업성장

JEL Classification: D24, O13, Q43

* 에너지경제연구원 연구위원

** 에너지경제연구원 부연구위원

*** 한국은행 조사국 선진경제팀장(前 경제연구원 미시제도연구실장)

이 연구내용은 집필자의 개인의견이며 한국은행의 공식견해와는 무관합니다. 따라서 본 논문의 내용을 보도하거나 인용할 경우에는 집필자명을 반드시 명시하여 주시기 바랍니다. 